Egypt. J. Aquat. Biol. \& Fish., Vol. 17, No. 4: 95- 103 (2013) ISSN 1110 - 6131

\title{
Effect of lessepsian immigrant species on demersal catches operating along the Egyptian Mediterranean waters
}

\author{
Shnoudy A. Bakhoum; Amal E. Philips and Evelyn Ragheb
}

National Institute of Oceanography and Fisheries, Alexandria, Egypt.

\section{ABSTRACT}

The present study was carried out on the lessepsian immigrant fishes caught with trawl nets in the Egyptian Mediterranean waters. Based on previously reported data during summer and winter 2008 and winter \& spring 2009, along the western and eastern Egyptian Mediterranean waters from El-Arish to El-Salloom using the research vessel "Salsabil" of the National Institute of Oceanography and Fisheries.

The relative abundance by number and weight of immigrant species represented $60.46 \%$ and $48.50 \%$ respectively from the total fish catch. El -Shalya region contained the most abundant species by number (94.41\%) and weight $(95.11 \%)$.

The analysis of variance test, indicated that differences in abundance of immigrant species in different water depths by number $(\mathrm{F}=1.225, \mathrm{p}>0.05)$ and by weight $(\mathrm{F}=1.235, \mathrm{p}>0.05)$ were not significant. The most common immigrant species was Erugosquilla massavensis, representing $26.61 \%$ by number, and Fistularia commersonii dominated the immigrant species catches by weight $(23.22 \%)$.

Immigrant fishes expanded their distribution up to El-Salloom at the western border of the Egyptian Mediterranean coast. The results of Shannon's Index ( $\left.\mathrm{H}^{\prime}\right)$ and Simpson's dominance index (c) led us to consider that the local community at depth 100-150 was more diverse than other habitats.

Keywords: The lessepsian immigrant species, trawl net catch, Egyptian Mediterranean waters.

\section{INTRODUCTION}

The south - eastern Egyptian Mediterranean coast has been subjected to effects of important events, such as the opening of the Suez Canal in 1869 and the construction of the Aswan High Dam in 1964 and the discharge of high rates of drainage water. The opening of the Suez Canal in 1869 connected the Red Sea to the Mediterranean and allowed the introduction of numerous Indo- Pacific species into the Mediterranean (Golani, 1998). The process of immigration through the Suez Canal increased from 12 species in 1882 to 92 alien species of Indo-Pacific origin in 2010 (Keller, 1882 and Zenetos et al., 2010).

The catch from the Egyptian waters accounted for about $5.92 \%$ of the total Mediterranean production in 1990. Its proportion was raised to $8.27 \%$ in 2006 , but no clear trend could be reliably inferred regarding the quality of the data provided by some of the member countries (Eurostat, 2008).

The catch from the Egyptian Mediterranean waters reached to 88882 tons in 2008, then was decreased to 77799 tons in 2011 (GAFRD, 2011).

Many of the lessepsian immigrant species are now apparently well established in the eastern Mediterranean and became an economically important item in the fisheries of the Egyptian Coast, such as Brush-tooth lizard fish, Saurida undosquamis, (Shenouda, 1986) and narrow-barred Spanish mackerel Scomberomorus commerson (Bakhoum, 2007). 
The purpose of this study was to reveal the successful propagation and economical importance of lessepsian immigrant species in the fisheries of Egyptian Mediterranean waters.

\section{MATERIALS AND METHODS}

An experimental trawling fishing survey was carried out during summer and winter 2008 and winter \& spring 2009, along the western and eastern Egyptian Mediterranean waters from El-Salloom to El-Arish, by using the research vessel "Salsabil" of the National Institute of Oceanography and Fisheries.

The fishing hauls were carried out at different depths $(<50,50-100$ and $>100 \mathrm{~m})$.

The catches of trawling operations were identified to species. For each fish, total length $(\mathrm{mm})$ and total weight $(\mathrm{g})$ were recorded.

Two types of Trawl nets of Japanese design were used in the El-Salsabil vessel, these were as follows.

1-The first one was with one cod-end type, its length was $36 \mathrm{~m}$ long, while the head rope reached about $28 \mathrm{~m}$. The stretched mesh size of such net was $160 \mathrm{~mm}$ at its wing. It ranged from $120 \mathrm{~mm}$ at the front belly to $60 \mathrm{~cm}$ for net belly, while the mesh size of the cod end was $30 \mathrm{~mm}$.

2-The second one was of two cod-ends, its head rope was $43.6 \mathrm{~m}$ and the footrope was $50 \mathrm{~m}$. The stretched mesh size of such net ranged gradually from $120 \mathrm{~mm}$ at its wing to $90 \mathrm{~mm}$ at the belly and $40 \mathrm{~mm}$ at the cod end. Two strengthening galvanized side lines (18mm thickness) were attached to the outer and inner sides of the belly and cod end. The outer rope measured $19.4 \mathrm{~m}$ and the inner rope measured $16.60 \mathrm{~m}$.

Biodiversity was calculated based on the formulae developed by ShannonWeaver (1949), Shannon's Index (H') and Simpson's dominance index, (c), (Simpson, 1949).

\section{RESULTS}

The relative abundance by number and weight of immigrant species in the Egyptian Mediterranean bottom catch revealed that, they represented $60.46 \%$ and $48.50 \%$ respectively (Table 1 ).

The variations in Abundance of immigrant species in different localities of the Egyptian Mediterranean water showed that, El -Shalya region contained the most abundant species by number $(94.41 \%)$ and weight $(95.11 \%)$ followed by Alam ElRom by number $(88.78 \%)$ and El-Arish by weight $(92.99 \%)$ (Table 1$)$.

Rate of expansion of immigrant species in the Egyptian Mediterranean waters showed that they expanded their distribution up to El-Salloom in the western border of the Egyptian Mediterranean coast (Fig. 1). 
Table 1: Abundance of immigrant species captured by trawl net in different localities of the Egyptian Mediterranean waters.

\begin{tabular}{|l|c|c|c|c|c|c|}
\hline \multirow{2}{*}{ Regions } & \multicolumn{2}{|c|}{ Total catch } & \multicolumn{2}{c|}{ Immigrant species catch } & \multicolumn{2}{c|}{ Abundance } \\
\cline { 2 - 7 } & Number & Weight $($ Kg $)$ & Number & Weight $(\mathrm{Kg})$ & N \% & W \% \\
& & & & & & \\
\hline El-Arish & $\mathbf{1 5 3 4}$ & $\mathbf{7 2 . 4 7}$ & $\mathbf{1 2 9 4}$ & $\mathbf{6 7 . 3 9}$ & $\mathbf{8 4 . 3 5}$ & $\mathbf{9 2 . 9 9}$ \\
Sahl El-Tina & $\mathbf{3 1 9}$ & $\mathbf{2 5 . 2 5}$ & $\mathbf{1 4 8}$ & $\mathbf{1 4 . 9 9}$ & $\mathbf{4 6 . 3 9}$ & $\mathbf{5 9 . 3 7}$ \\
Damietta & $\mathbf{5 9 3}$ & $\mathbf{1 4 3 . 1 2}$ & $\mathbf{4 1 3}$ & $\mathbf{7 7 . 0 6}$ & $\mathbf{6 9 . 6 5}$ & $\mathbf{5 3 . 8 4}$ \\
El-Manzalah & $\mathbf{3 3 8}$ & $\mathbf{2 1 . 1 6}$ & $\mathbf{1 6 2}$ & $\mathbf{8 . 1 9}$ & $\mathbf{4 7 . 9 3}$ & $\mathbf{3 8 . 7 1}$ \\
Baltim & $\mathbf{7 5 7}$ & $\mathbf{4 9 . 9 1}$ & $\mathbf{5 7 6}$ & $\mathbf{2 1 . 8 7}$ & $\mathbf{7 6 . 0 9}$ & $\mathbf{4 3 . 8 2}$ \\
Gamasa & $\mathbf{6 9 0}$ & $\mathbf{5 2 . 1 4}$ & $\mathbf{5 1 2}$ & $\mathbf{2 0 . 2 6}$ & $\mathbf{7 4 . 2}$ & $\mathbf{3 8 . 8 6}$ \\
El Brulous & $\mathbf{2 1 2}$ & $\mathbf{1 5 . 3 7}$ & $\mathbf{7 4}$ & $\mathbf{4 . 4 6}$ & $\mathbf{3 4 . 9 1}$ & $\mathbf{2 9 . 0 2}$ \\
Rosaetta & $\mathbf{1 1 8 1}$ & $\mathbf{1 1 2 . 7 9}$ & $\mathbf{6 6 9}$ & $\mathbf{7 7 . 0 6}$ & $\mathbf{5 6 . 6 5}$ & $\mathbf{6 8 . 3 2}$ \\
Abu-Qir & $\mathbf{8 3 8}$ & $\mathbf{1 7 0 . 7 8}$ & $\mathbf{3 4 9}$ & $\mathbf{4 3 . 4 0}$ & $\mathbf{4 1 . 6 5}$ & $\mathbf{2 5 . 4 1}$ \\
San Stefano & $\mathbf{2 2 1}$ & $\mathbf{8 . 9 6}$ & $\mathbf{1 8 3}$ & $\mathbf{7 . 7 3}$ & $\mathbf{8 2 . 8 1}$ & $\mathbf{8 6 . 2 7}$ \\
Eastern harbor & $\mathbf{4 1 3}$ & $\mathbf{2 9 . 8 6}$ & $\mathbf{2 0 7}$ & $\mathbf{1 1 . 0 1}$ & $\mathbf{5 0 . 1 2}$ & $\mathbf{3 6 . 8 7}$ \\
EL-Hamam & $\mathbf{1 3 1}$ & $\mathbf{8 . 4 9}$ & $\mathbf{3 3}$ & $\mathbf{2 . 3 2}$ & $\mathbf{2 5 . 1 9}$ & $\mathbf{2 7 . 3 3}$ \\
El-Alamain & $\mathbf{3 4 4}$ & $\mathbf{3 0 . 3 8}$ & $\mathbf{2 5 4}$ & $\mathbf{1 3 . 6 9}$ & $\mathbf{7 3 . 8 4}$ & $\mathbf{4 5 . 0 6}$ \\
El-Dabah & $\mathbf{1 7 0}$ & $\mathbf{2 1 . 8 1}$ & $\mathbf{5 6}$ & $\mathbf{1 3 . 4 2}$ & $\mathbf{3 2 . 9 4}$ & $\mathbf{6 1 . 5 3}$ \\
Foka & $\mathbf{3 8 2}$ & $\mathbf{1 5 . 3 2}$ & $\mathbf{2 8 6}$ & $\mathbf{1 3 . 0 6}$ & $\mathbf{7 4 . 8 7}$ & $\mathbf{8 5 . 2 5}$ \\
Ras EL-Hekma & $\mathbf{5 6}$ & $\mathbf{2 4 . 1 5}$ & $\mathbf{2 6}$ & $\mathbf{4 . 8 5}$ & $\mathbf{4 6 . 4 3}$ & $\mathbf{2 0 . 0 8}$ \\
El -Shalya & $\mathbf{1 4 3}$ & $\mathbf{1 2 . 0 6}$ & $\mathbf{1 3 5}$ & $\mathbf{1 1 . 4 7}$ & $\mathbf{9 4 . 4 1}$ & $\mathbf{9 5 . 1 1}$ \\
Alam El-Rom & $\mathbf{9 8}$ & $\mathbf{1 1 . 7 6}$ & $\mathbf{8 7}$ & $\mathbf{9 . 6 2}$ & $\mathbf{8 8 . 7 8}$ & $\mathbf{8 1 . 8 0}$ \\
Marsa Matroh & $\mathbf{4 9}$ & $\mathbf{2 . 4 2}$ & $\mathbf{3 7}$ & $\mathbf{1 . 4 9}$ & $\mathbf{7 5 . 5 1}$ & $\mathbf{6 1 . 5 7}$ \\
Sedi brani & $\mathbf{3 4 7}$ & $\mathbf{2 6 . 4 8}$ & $\mathbf{1 0 6}$ & $\mathbf{6 . 3 8}$ & $\mathbf{3 0 . 5 5}$ & $\mathbf{2 4 . 0 9}$ \\
El-Salloom & $\mathbf{8 7 8}$ & $\mathbf{4 8 . 4 4}$ & $\mathbf{2 5 4}$ & $\mathbf{8 . 3 0}$ & $\mathbf{2 8 . 9 3}$ & $\mathbf{1 7 . 1 3}$ \\
\hline \multicolumn{1}{|c|}{ Total } & $\mathbf{9 6 9 4}$ & $\mathbf{9 0 3 . 1 2}$ & $\mathbf{5 8 6 1}$ & $\mathbf{4 3 8 . 0 2}$ & $\mathbf{6 0 . 4 6}$ & $\mathbf{4 8 . 5 0}$ \\
\hline
\end{tabular}

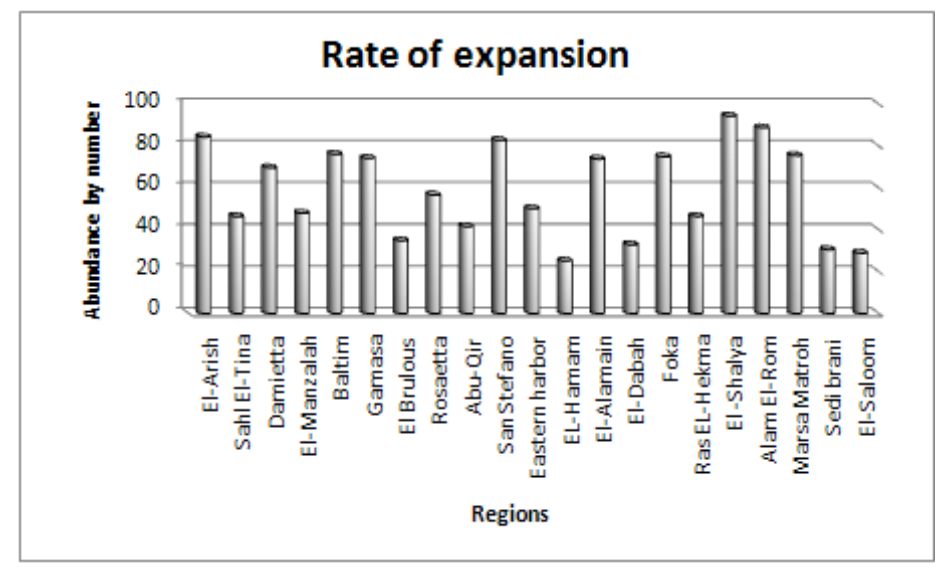

Fig. 1: Rate of expansion of immigrant species captured by trawl net in the Egyptian Mediterranean waters.

Erugosquilla massavensis dominated the immigrant species catches by number $(26.61 \%)$ and Fistularia commersonii by weight $(23.22 \%)$, while the second rank was represented by Leiognathus klunzingeri (13.24\%) by number and Lagocephalus spadiceus (19.69\%) by weight (Table 2).

Catch percentage by number and weight of economic \& non- economic immigrant species captured by trawl net in the Egyptian Mediterranean waters revealed that fishes dominated the immigrant species by weight $(82.56 \%)$ and number (63.56\%) (Fig. 2a). Catch percentage by number and weight of economic \& noneconomic immigrant fishes showed that non-economic species were more abundant by weight and number (75.41\% \& 59.33\% respectively) (Fig. 2b), Meanwhile, the non-economic immigrant species showed that the non-economic fishes were more abundant by weight $(78.12 \%)$ and number $(50.85 \%)$ to the non- economic species 
captured by trawl net, while, the crustacean species were $21.88 \% \& 49.15 \%$ by weight and number respectively to the non- economic species captured by trawl net. (Fig. 2c).

Table 2: Abundance by number and weight of immigrant species captured by trawl net in the Egyptian Mediterranean waters.

\begin{tabular}{|c|c|c|c|c|}
\hline \multirow[b]{2}{*}{ Species } & \multicolumn{4}{|c|}{ Abundance } \\
\hline & Number & $\mathrm{N} \%$ & $\begin{array}{c}\text { Weight } \\
(\mathrm{gm})\end{array}$ & $\mathrm{W} \%$ \\
\hline \multicolumn{5}{|c|}{ The most economic species: } \\
\hline \multicolumn{5}{|l|}{ I. Fishes: } \\
\hline Stephanolepis diaspros & 100 & 12.61 & 3153 & 6.61 \\
\hline Saurida undosquamis & 39 & 4.92 & 3059 & 6.41 \\
\hline Scomberomorus commerson & 36 & 4.54 & 2890 & 6.06 \\
\hline Siganus rivulatus & 24 & 3.03 & 516 & 1.08 \\
\hline Alepes djedaba & 5 & 0.63 & 66 & 0.14 \\
\hline Siganus luridus & 1 & 0.13 & 3 & 0.01 \\
\hline Total & 205 & & 9687 & \\
\hline \multicolumn{5}{|l|}{$\begin{array}{l}\text { The non-economic species: } \\
\text { I. Fishes: }\end{array}$} \\
\hline Leiognathus klunzingeri & 105 & 13.24 & 465 & 0.97 \\
\hline Fistularia commersonii & 72 & 9.08 & 11078 & 23.22 \\
\hline Terapon puta & 59 & 7.44 & 2933 & 6.15 \\
\hline Himantura uarnak & 15 & 1.89 & 4228 & 8.86 \\
\hline Lagocephalus spadiceus & 14 & 1.77 & 9396 & 19.69 \\
\hline Lagocephalus scleratus & 8 & 1.01 & 748 & 1.57 \\
\hline Etrumeus teres & 8 & 1.01 & 223 & 0.47 \\
\hline Upeneus moluccensis & 8 & 1.01 & 185 & 0.39 \\
\hline Nemipterus japonicus & 5 & 0.63 & 431 & 0.90 \\
\hline Pteragogus pelycus & 4 & 0.50 & 8 & 0.02 \\
\hline Upeneus pori & 1 & 0.13 & 15 & 0.03 \\
\hline Total & 299 & & 29710 & \\
\hline \multicolumn{5}{|l|}{ II. Crustacea } \\
\hline Erugosquilla massavensis & 211 & 26.61 & 3511 & 7.36 \\
\hline Metapenaeus monoceros & 64 & 8.07 & 345 & 0.72 \\
\hline Portunus pelagicus & 14 & 1.77 & 4465 & 9.36 \\
\hline Total & 289 & & 8321 & \\
\hline Total & 793 & & 47718 & \\
\hline
\end{tabular}



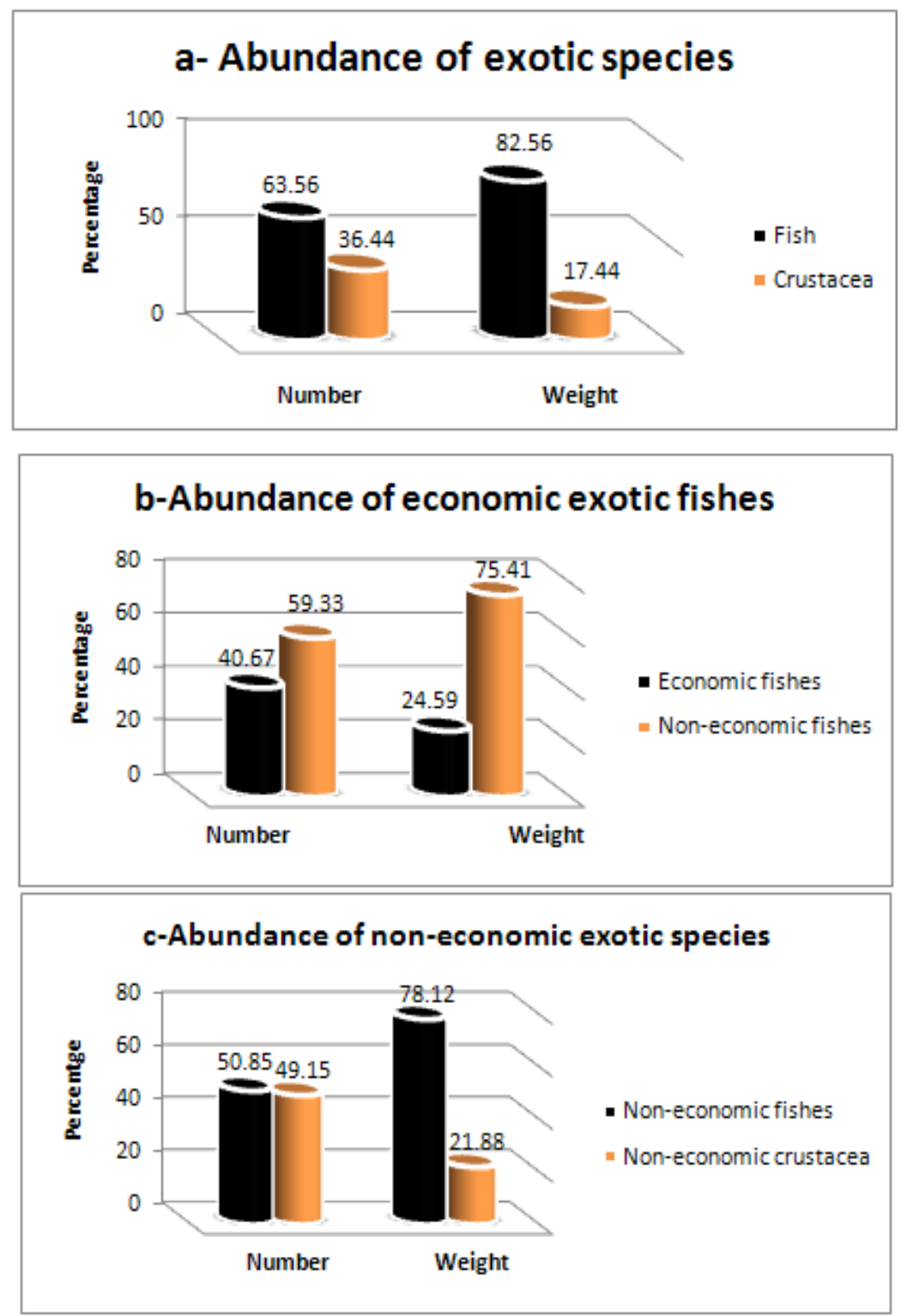

Fig. 2: Catch percentage by number and weight of immigrant species for: a- Exotic species, bEconomic exotic fish, c- Non-economic exotic species, captured by trawl net in the Egyptian Mediterranean waters.

The most common economic fish species was Stephanolepis diaspros representing $32.55 \%$ by weight and $48.78 \%$ by number followed by Saurida undosquamis $(31.58 \%$ by weight $\& 19.02 \%$ by number) of the most economic fish species. The most common non-economic fish species by weight was Fistularia commersonii $(37.29 \%)$ of the non-economic fish species, while Leiognathus klunzingeri was dominated by number $(35.12 \%)$ of the non-economic fish species. The most common non-economic crustacean species was Portunus pelagicus representing $53.66 \%$ by weight of the non-economic crustacean species, while Erugosquilla massavensis dominated by number (73.01\%) of the non-economic crustacean species.

The comparison between abundance of immigrant species at different water depths using the analysis of variance test, indicated that differences in abundance by 
number $(\mathrm{F}=1.225, \mathrm{p}>0.05)$ and by weight $(\mathrm{F}=1.235, \mathrm{p}>0.05)$ were not significant (Table 3, Fig. 3).

Table 3: Abundance of immigrant species captured by trawl net in different depth of the Egyptian Mediterranean waters.

\begin{tabular}{|c|c|c|c|c|c|c|}
\hline \multirow{2}{*}{ Depth } & \multicolumn{2}{|c|}{ Total catch } & \multicolumn{2}{c|}{ Immigrant species catch } & \multicolumn{2}{c|}{ Abundance } \\
\cline { 2 - 7 } & Number & Weight $(\mathrm{Kg})$ & Number & Weight $(\mathrm{Kg})$ & N\% & W\% \\
\hline$>50$ & 4411 & 405.54 & 2474 & 173.86 & 56.09 & 42.87 \\
$50-100$ & 2977 & 226.87 & 1516 & 94.78 & 50.92 & 41.78 \\
$100-150$ & 430 & 30.01 & 275 & 11.58 & 63.95 & 38.59 \\
$150-250$ & 757 & 38.69 & 442 & 25.75 & 58.39 & 66.55 \\
\hline
\end{tabular}

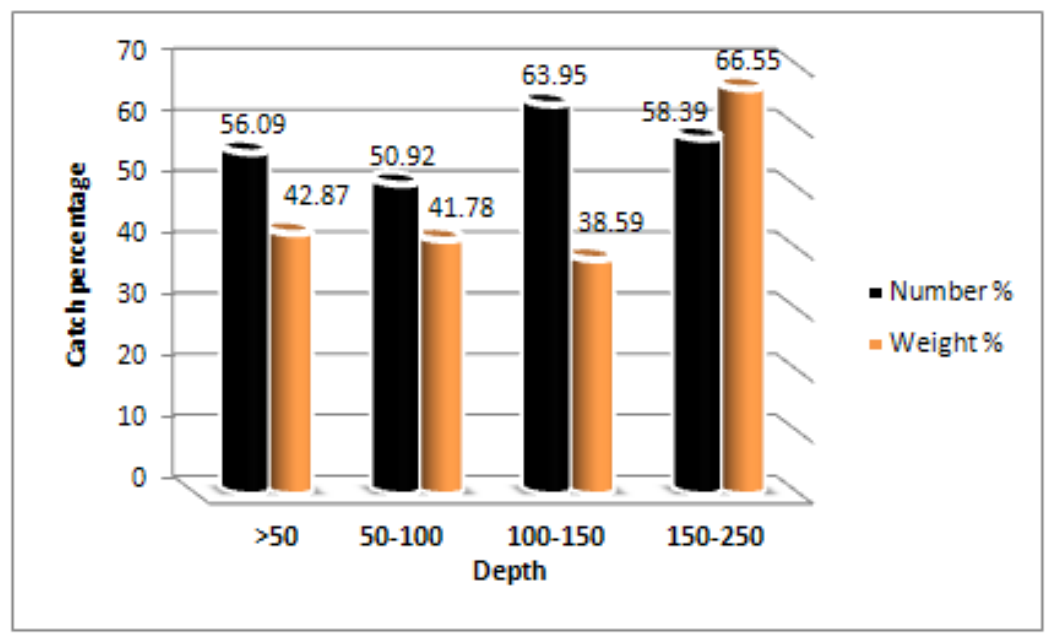

Fig. 3: Catch percentage by number and weight of immigrant species captured by trawl net in different depth of the Egyptian Mediterranean waters.

The immigrant species revealed inhabitation variations at different depths of the Egyptian Mediterranean waters. Most of them were found at depth from 50 to $100 \mathrm{~m}$ (13 species) while at water depth less than 50m (10 species). Three immigrant species were found at depth from 150 to 250 meter, while two species inhabited depth from 100 to 150 meter. Only Nemipterus japonicus were found at different water depths (Table 4).

The results of Shannon's Index ( $\left.\mathrm{H}^{\prime}\right)$ and Simpson's dominance index (c) led us to consider the local community at depth 100-150 was more diverse than others followed by depth 150 to 250 , while $50-100$ and $<50$ depth, communities represented the third and fourth rank respectively (Table 5). 
Table 4: The immigrant species captured by trawl net in different depth of the Egyptian Mediterranean waters.

\begin{tabular}{|c|c|c|c|c|}
\hline \multirow{2}{*}{ Species } & \multicolumn{4}{|c|}{ Depth } \\
\hline & $>50$ & $50-100$ & $100-150$ & $150-250$ \\
\hline \multicolumn{5}{|l|}{ Economic species: } \\
\hline Stephanolepis diaspros & + & & & \\
\hline Saurida undosquamis & & + & & + \\
\hline Scomberomorus commerson & + & + & & \\
\hline Siganus rivulatus & + & + & & \\
\hline Alepes djedaba & + & & & \\
\hline Siganus luridus & & + & & \\
\hline \multicolumn{5}{|l|}{ Non-economic species: } \\
\hline \multicolumn{5}{|l|}{ I. Fishes: } \\
\hline Leiognathus klunzingeri & + & & & \\
\hline Fistularia commersonii & & + & & \\
\hline Terapon puta & + & & & + \\
\hline Himantura uarnak & & + & & \\
\hline Lagocephalus spadiceus & & + & & \\
\hline Lagocephalus scleratus & & + & & \\
\hline Etrumeus teres & + & & & \\
\hline Upeneus moluccensis & + & . & & \\
\hline Nemipterus japonicus & + & + & + & + \\
\hline Pteragogus pelycus & & + & & \\
\hline Upeneus pori & & + & & \\
\hline \multicolumn{5}{|l|}{ II. Crustacea: } \\
\hline Erugosquilla massavensis & & + & & \\
\hline Metapenaeus monoceros & + & & + & \\
\hline Portunus pelagicus & & + & & \\
\hline
\end{tabular}

Table 5: The diversity of immigrant species captured by trawl net in different depth of the Egyptian Mediterranean waters.

\begin{tabular}{|l|c|c|}
\hline Depth & Shannon's Index $\left(\mathrm{H}^{\prime}\right)$ & Index of Dominance $(\mathrm{C})$ \\
\hline Depth $>50$ & $0.35 \pm 0.01$ & $0.13 \pm 0.33$ \\
\hline Depth $50-100$ & $0.52 \pm 0.15$ & $0.19 \pm 0.20$ \\
\hline Depth $100-150$ & $0.66 \pm 0.04$ & $0.50 \pm 0.42$ \\
\hline Depth $150-250$ & $0.65 \pm 0.28$ & $0.37 \pm 0.36$ \\
\hline
\end{tabular}

\section{DISCUSSIONS}

The increased awareness of the impact of alien species on native biodiversity led to intensified research efforts on immigrant fish's communities and their role on the Mediterranean fisheries.

Endemic species represent only $28-29 \%$ of the Mediterranean fauna. Atlantic origin species were dominating (50.2\%), while Atlantic-Pacific origin and IndoPacific origin species were represented by $16.8 \%$ and $4.4 \%$ respectively (Emig and Geistdoerfer, 2004).

The catch from the Egyptian Mediterranean waters was increased as percent of the total Mediterranean production (Eurostat, 2008) It is not only attributed to increase fish efforts but also to increased rate of immigrant fishes in total catch. Recently, many of immigrant species are playing important role in raising fish production. Halim and Rizkalla (2011) gave a check-list of 42 immigrant Erythrean fish in Egyptian Mediterranean where 17 of them are commercially exploited.

The ecologists consider the spread of "invasive" species as a major threat to biodiversity in the marine environment (Dukes, 2003). The spread of non-native 
species into the Mediterranean depends on its ability to adapt in host environment and food competition with relative species. The water salinity plays an important role in the distribution of invasive aliens, whereas Fistularia commersonii inhabit high salinity water west of Egyptian Mediterranean coast. Some non- native species were proved to be highly euryhaline, which is being able to penetrate to a wide salinity range such as Terapon puta, which was spread from east to west of Egyptian Mediterranean waters. In addition, water temperature determined the distribution of immigrant species in Mediterranean waters, whereas only 16 of these exotic species have extended their distribution as far as the Aegean Sea (Golani et al., 2002). These exotic species inclouding Scomberomorus commerson, Alpes djedaba, Stephanolepis diaspros, Fistularia commersonii, Siganus rivulatus, Siganus luridus and Saurida undosquamis showed that the environmental conditions in the East and the North of the Mediterranean Sea satisfy their its requirements for successful adaptation in the new habitat. Saurida undosquamis has increased in the Mediterranean Sea in subsequent years, to the point that it is now considered as an important economic species on the Asian Coast (Ben-Yami and Glaser, 1974) and the Egyptian Coast (Wadie and Shnenouda, 1985; Shnenouda, 1986). Bakhoum (2007) found that the diet and feeding habits of immigrant predator Scomberomorus commerson to the Levant Basin of the Mediterranean Sea are similar to Trichiurus lepturus. Competition for fish prey is not a major determinant of propagation of Scomberomorus commerson due to the increasing numbers of the dominant food prey "anchovy" in the Egyptian Mediterranean waters.

The invasive species not only have adverse impact on biodiversity but also on human health ,the puffer fish, Lagocephalus spp., which proved to be a serious hazard to consumers, causing lethal cases due to tetrodotoxin, a poisonous substance (Halim and Rizkalla, 2011). On the other hand, it should not be forgotten that several examples can be given, demonstrating that many exotic species has been of economic benefit. The statistics of GAFRD, (2011) showed that Scomberomorus commerson, Siganus spp. and Saurida undosquamis are playing important role in raising Egyptian fish production from Mediterranean waters.

\section{ACKNOWLEDGEMENTS}

The authors wish to express their sincere thanks to all the scientific staff of the research vessel "Salsabil" and all the fisheries staff of the National Institute of Oceanography and Fisheries, Alexandria for their help in collecting the material on which this paper is based.

\section{REFERENCE}

Bakhoum, S. A. (2007). Diet overlap of immigrant narrow-barred Spanish mackerel Scomberomorus commerson (Lac., 1802) and the large head hair tail ribbonfish Trichiurus lepturus (L., 1758) in the Egyptian Mediterranean coast. Animal Biodiversity Conservation, 30(2): 147-160.

Ben-Yami, M., Glaser, T. (1974). The invasion of Saurida undosquamis Into the Levant Basin. An example of biological effect of interoceanic Canal. U.S. Natl. Mar. Fish Serv. Fish. Bull. 72 (2): 359-373.

Dukes, J. (2003). Hotter and weedier? Effects of climate change on the success of invasive species. In: Global climate change and biodiversity. R. E.Green, M. Hartley, L. Miles, J. Scharlemann, A . Watson \& O. Watts (Eds). Tyndall Center for Climate Change Research, Norwich. 
Emig, C.C., Geistdoerfer, P. (2004). The Mediterranean deep-sea fauna: historical evolution, bathymetric variations and geographical changes. Carnets de Géologie / Notebooks on Geology, Maintenon, Article 2004/01.

Eurostat, Statistics in focus (2008). Half of Mediterranean fish catches are by Mediterranean Partner Countries. Available from: http: // www. ec.europa.eu/eurostat/medstat.

GAFRD (2011). General Authority for fish resources development, data on fish production in Egypt, Ministry of Agriculture, Cairo.

Golani, D. (1998). Impact of Red Sea fish migrants through the Suez Canal on the aquatic environment of the eastern Mediterranean. Yale F\&ES Bulletin 103: 375-387.

Golani, D., Orsi-Relini, L., Massuti, E. \& Quignard, J.-P. (2002). CIESM Atlas Exotic species in the Mediterranean. Vol. 1. Fishes. F. Briand (Ed). Monaco, 254pp.

Halim, Y and Rizkalla, S. (2011). Aliens in Egyptian Mediterranean waters. A check-list of Erythrean fish with new records. Medit. Mar. Sci., 12 (2): 479- 490.

Keller, C. (1882). Die fauna in Suez Canal und die diffusion der Mediterranean und Erythraischen Tierwelt. Neue Denkschriften der allgemeinen Schweizerischen Gesellschaft für die gesamten naturwissenschaften, 28 (3):1-28.

Shenouda, T. S. (1986). Some details on the immigration process through the Suez Canal, with a special note on the appearance and spreading of Saurida undosquamis (Richardson), in the Mediterranean Sea. Delta, J. Sci., 10(2):1071-1087.

Simpson, E.H. (1949). Measurement of diversity. Nature, Lond. 163: 688PP.

Shannon, C.E., Weaver, W. (1949). The mathematical theory of communication. The University of Illinois Press, Urbana, 117pp.

Wadie, W. F., Shenouda, T. S. (1985). Role of the Suez Canal and stock of the River Nile in changing the salinity regime and fauna of the Mediterranean

Sea. J. Ikhthiol, 25 (1): 155-156.

Zenetos, A., Gofas, S., Verlaque, M., Cinar, M.E., Bianchi, C.N. (2010). Alien species in the Mediterranean Sea by 2010. A contribution to the application of European Union's Marine Strategy Framework Directive. Part I. Spatial Distribution. Medit. Mar. Sci., 11 (2): 381-493.

\section{ARABIC SUMMARY}

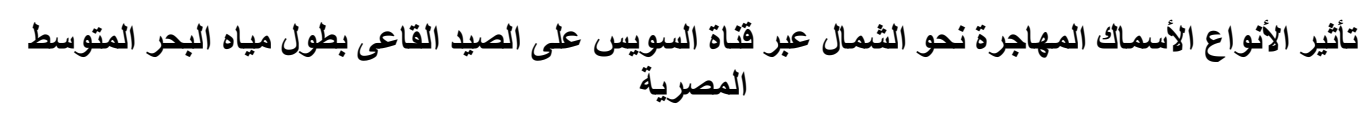

$$
\begin{aligned}
& \text { شنودى أنور باخوم - آمال إسكندر فيلبس - ايفيلين راغب المبار }
\end{aligned}
$$

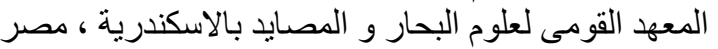

أوضحت هذه الدراسة حالة الأسماك المهاجرة الى شمال قناة السويس المصادة بشبالك الجر في مياه البحر

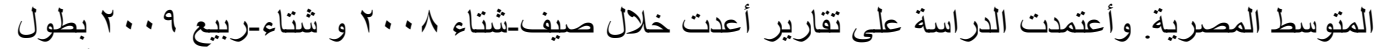

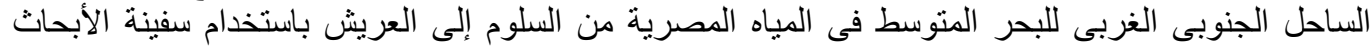

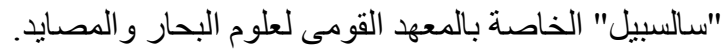

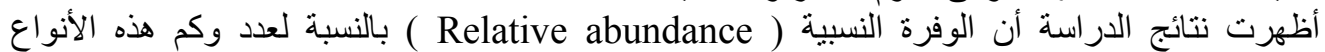

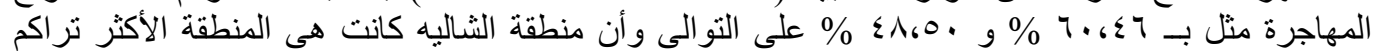

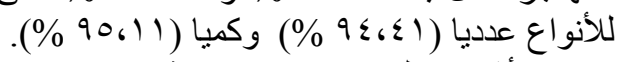

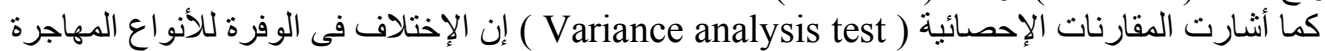

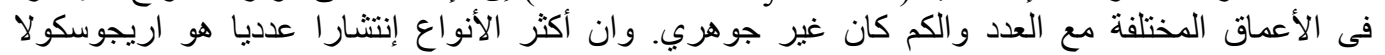

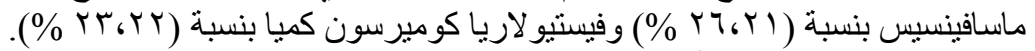

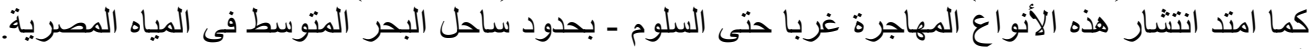

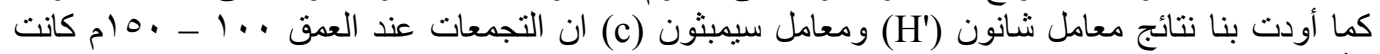

الأكثر اختلافا. 